\title{
Hospital preparedness for Ebola virus disease: a training course in the Philippines
}

\author{
Celia Carlos, ${ }^{a}$ Rowena Capistrano, ${ }^{a}$ Charissa Fay Tobora, ${ }^{a}$ Mari Rose delos Reyes, ${ }^{a}$ Socorro Lupisan, ${ }^{\circ}$

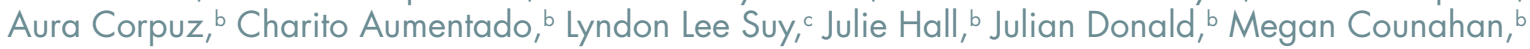 \\ Melanie S Curless, ${ }^{d}$ Wendy Rhymer, ${ }^{,}$Melanie Gavin, ${ }^{d}$ Chelsea Lynch, ${ }^{d}$ Meredith A Black, ${ }^{d}$ Albert D Anduyon, ${ }^{a}$ \\ Petra Buttner ${ }^{f}$ and Rick Speare ${ }^{f, g}$ \\ Correspondence to Rick Speare (e-mail: rickspeare@gmail.com).
}

Objective: To develop, teach and evaluate a training workshop that could rapidly prepare large numbers of health professionals working in hospitals in the Philippines to detect and safely manage Ebola virus disease (EVD). The strategy was to train teams (each usually with five members) of key health professionals from public, private and local government hospitals across the Philippines who could then guide Ebola preparedness in their hospitals.

Methods: The workshop was developed collaboratively by the Philippine Department of Health and the country office of the World Health Organization. It was evaluated using a pre- and post-workshop test and two evaluation forms. Chi-square tests and linear regression analyses were conducted comparing pre- and post-workshop test results.

Results: A three-day workshop was developed and used to train 364 doctors, nurses and medical technologists from 78 hospitals across the Philippines in three initial batches. Knowledge about EVD increased significantly $(P<0.009)$ although knowledge on transmission remained suboptimal. Confidence in managing EVD increased significantly $(P=0.018)$ with $96 \%$ of participants feeling more prepared to safely manage EVD cases.

Discussion: The three-day workshop to prepare hospital staff for EVD was effective at increasing the level of knowledge about EVD and the level of confidence in managing EVD safely. This workshop could be adapted for use as baseline training in EVD in other developing countries to prepare large numbers of hospital staff to rapidly detect, isolate and safely manage EVD cases.

$\mathrm{T}$ he West African Ebola virus disease (EVD) outbreak was declared a public health emergency of international concern (PHEIC) by the World Health Organization (WHO) on 8 August 2014. ${ }^{1}$ This outbreak is unprecedented with ongoing transmission in Guinea, Liberia and Sierra Leone and secondary localized outbreaks in Mali, Nigeria, Spain and the United States of America. Although estimates vary, the case fatality rate (CFR) is high in the three West African countries with ongoing transmission: cumulative CFR for the outbreak on 24 December 2014 was 70\% for cases with a recorded definitive outcome; 58-60\% for hospitalized patients; and 55\% (359/649) for healthcare workers (HCWs). ${ }^{2}$ Using the total figures for Guinea, Liberia and Sierra Leone gives a cumulative CFR of 39\% (7574/19 463) for all probable and confirmed cases, an underestimate of CFR since the fate of apparently more than 2000 cases are unknown. ${ }^{2}$ This EVD outbreak was the third PHEIC to be declared under the International Health Regulations (2005) (IHR). IHR is a legal framework that directs and governs its signatories' activities, aiming to protect the global community from public health risks and emergencies that cross international borders. ${ }^{3}$ At its core is the obligation for countries to develop, strengthen and maintain public health capacities for surveillance and response to be able to detect, assess, notify and report events and respond to a PHEIC. ${ }^{3}$

The West African EVD outbreak is considered such a threat to global security that for the first time the United Nations General Assembly, supported by the United Nations Security Council, mandated a United Nations Mission for Ebola Emergency Response for a public health event. ${ }^{4}$

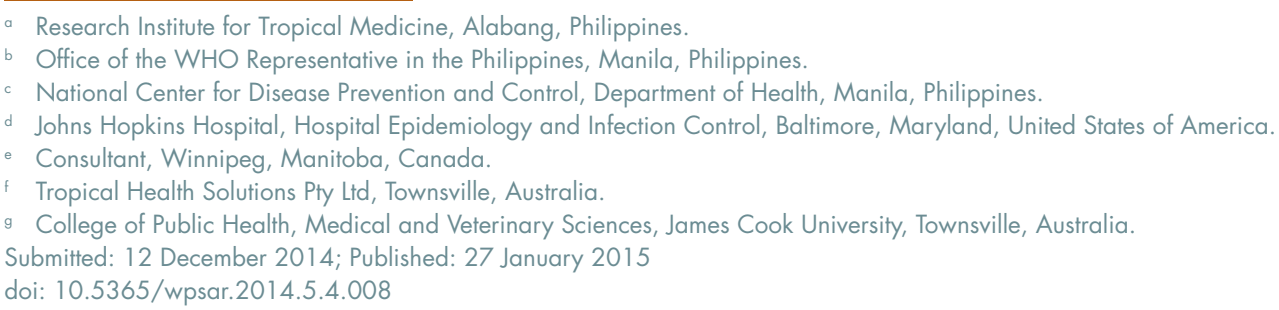


In 2013 the Philippines had 2.295 million formally registered Overseas Filipino Workers (OFW). ${ }^{5}$ Of these, $1700(<1 \%)$ were registered in Africa. However, the Commission on Filipinos Overseas estimated in 2012 there were 10.46 million Filipinos working overseas either permanently or temporarily. ${ }^{6}$ Their estimate in the Ebola-affected countries of Guinea, Liberia and Sierra Leone was $1212 .{ }^{6}$ It is traditional for OFW to return to the Philippines in high numbers at Christmas time. ${ }^{7}$

The Philippine Department of Health ( $\mathrm{DOH})$ is experienced with the management of outbreaks and has a relatively robust surveillance system with a history of managing imported emerging and re-emerging infectious diseases. ${ }^{8-10}$

It was against this backdrop of the risk of global transmission and returning OFW that the $\mathrm{DOH}$ asked the WHO country office in the Philippines for assistance in designing and implementing a training workshop to prepare government and private health practitioners in the management of EVD.

Countries unaffected by EVD, such as the Philippines, are required to prepare for the introduction of cases. Even if no EVD cases occur, symptomatic travellers from West Africa who meet the case definition of suspected EVD have to be managed according to the same protocols until they are confirmed as EVD negative. ${ }^{11}$ Although briefings for health care workers (HCWs) in Ebola treatment centres have been published, ${ }^{12-14}$ we were unable to locate a course designed to prepare clinicians for imported EVD in developing country settings.

The goal of the training was to increase capacity to rapidly detect, isolate and safely care for EVD cases within the Philippine health system, both public and private. The aims of the workshop were for participants to be able to provide safer care for patients with EVD and to prevent disease transmission in the health-care and community settings. The strategy was to train teams (each usually with five members) of key health professionals from public, private and local government hospitals across the Philippines who could then guide Ebola preparedness in their hospitals. The focus was on hospitals since it is highly likely that, if EVD occurs in the Philippines, patients will be identified and managed in hospitals. Although the DOH has appointed some hospitals to be EVD referral hospitals, the initial presentation of cases could occur at any hospital.
To ensure that participants followed official guidelines, the workshop was based on the DOH's Interim Guidelines for the Prevention and Management of Ebola Virus Disease (26 August 2014).

The aim of this paper is to describe the training programme and its evaluation.

\section{METHODS}

\section{Setting}

The curriculum and content were developed collaboratively by the Research Institute for Tropical Medicine (RITM, the $\mathrm{DOH}$ research institute for infectious diseases), the WHO country office and consultants employed by WHO as private individuals or from Johns Hopkins Hospital and Tropical Health Solutions. RITM, located in Metropolitan Manila, has a large training centre and staff experienced in running workshops. Training laboratories were available for practical sessions, and RITM's infection control team (experienced with SARS and other emerging infectious diseases) played a major role.

\section{Workshops}

Each workshop extended over three days and consisted of 18 lectures and 10 practical or small group sessions, including three practical sessions to don (put on) and doff (take off) personal protective equipment (PPE) (Table 1). ${ }^{15}$ Everyone participated in at least two PPE sessions. At registration, every participant was given one set of PPE (apart from rubber boots) for personal use during the workshop. The PPE sessions were conducted in large groups numbering from 50 to 120 (Figure 1). PPE donning and doffing skills were first demonstrated to the whole group, which was then divided into two groups for demonstration and practice. Rigid donning and doffing protocols were followed and overseen by participants acting as trained observers supervised by course facilitators. In the final PPE session, red water-based paint was applied to the PPE to simulate contamination by body fluids, adding a sense of realism to the doffing process (Figure 2).

A specialized series of three lectures and a practical session were run separately for medical technologists (Table 1). In the Philippines, medical technologists have a Bachelor of Science in Medical Technology and are equivalent to laboratory scientists in other countries. The 


\section{Table 1. Structure of workshop on hospital management of EVD*}

\begin{tabular}{|c|c|c|}
\hline Session & Type of activity & Materials used \\
\hline \multicolumn{3}{|l|}{ Day 1} \\
\hline Opening & $\begin{array}{l}\text { Formal opening with support from } \\
\text { WHO country office and DOH }\end{array}$ & \\
\hline Introduction & Lecture & \\
\hline $\begin{array}{l}\text { Ebola - basics, natural history and epidemiology of the } \\
\text { West African outbreak; Reston Ebolavirus in the Philippines }\end{array}$ & Lectures & \\
\hline Screening and triage & Lecture; small group work on six cases & $\begin{array}{l}\text { Participants' sheet of cases } \\
\text { Facilitators' guide } \\
\text { Appendices B.2 and B. } 3 \text { of the DOH } \\
\text { Interim Guidelines }\end{array}$ \\
\hline Treatment and discharge & Lecture & \\
\hline Laboratory support and biosafety & Lecture & \\
\hline Laboratory confirmation of EVD & Lecture & \\
\hline Infection control for EVD & $\begin{array}{l}\text { Lecture } \\
\text { Practical session on removing gloves }\end{array}$ & $\begin{array}{l}\text { Individual gloves and alcohol-based hand } \\
\text { rub } \\
\text { Glow-powder and UV lights }\end{array}$ \\
\hline Ethical issues about clinical activities in EVD patients & Group discussion & \\
\hline PPE for EVD: donning and doffing & $\begin{array}{l}\text { Demonstration } \\
\text { Practical sessions }\end{array}$ & $\begin{array}{l}\text { Donning and doffing schedules } \\
\text { Facilitators' guide } \\
\text { Individual PPE }\end{array}$ \\
\hline \multicolumn{3}{|l|}{ Day 2} \\
\hline Isolation and patient flow & Lecture & \\
\hline Designing isolation units for your hospital & Practical session & Plans of each participant's hospital \\
\hline $\begin{array}{l}\text { Management of sharps and post-exposure management for } \\
\text { EVD }\end{array}$ & $\begin{array}{l}\text { Lecture } \\
\text { Role plays }\end{array}$ & \\
\hline Environmental cleaning and waste management for EVD & Lecture & \\
\hline Transport of EVD patients & Lecture & \\
\hline PPE for EVD: donning and doffing & Practical sessions & $\begin{array}{l}\text { Donning and doffing schedules } \\
\text { Facilitators' guide } \\
\text { Individual PPE }\end{array}$ \\
\hline \multicolumn{3}{|l|}{ Day 3} \\
\hline Comment on plans for isolation units & $\begin{array}{l}\text { Commentary of each group's plans for an } \\
\text { isolation unit in their hospital }\end{array}$ & $\begin{array}{l}\text { Photographs of individual hospital isolation } \\
\text { plans in PowerPoint presentation }\end{array}$ \\
\hline Community health and support & Lecture & \\
\hline Staff health and support in EVD & Lecture & \\
\hline Safe and dignified burial for EVD & Lecture & \\
\hline Epidemic management and surveillance & Lecture & \\
\hline Contact tracing & Lecture & \\
\hline Role of subnational laboratories & Lecture & \\
\hline $\begin{array}{l}\text { Question and answer session relevant to hospital } \\
\text { management of EVD }\end{array}$ & Interactive session with $\mathrm{DOH}$ representative & \\
\hline PPE for EVD: donning and doffing & $\begin{array}{l}\text { Practical session with addition of red water- } \\
\text { based paint used to contaminate PPE }\end{array}$ & $\begin{array}{l}\text { Donning and doffing schedules } \\
\text { Facilitators' guide } \\
\text { Individual PPE } \\
\text { Water-based paint }\end{array}$ \\
\hline \multicolumn{3}{|l|}{ Additional specialized workshop for medical technologists } \\
\hline EVD risk assessment and biosafety for laboratory personnel & Lecture & \\
\hline Referral system, transport and storage of EVD specimens & Lecture & \\
\hline $\begin{array}{l}\text { Laboratory waste management, decontamination and } \\
\text { laboratory emergencies for EVD }\end{array}$ & Lecture & \\
\hline Laboratory procedures with PPE for EVD & $\begin{array}{l}\text { Practical sessions: blood collection, } \\
\text { specimen processing; packaging for } \\
\text { transport }\end{array}$ & $\begin{array}{l}\text { Individual PPE } \\
\text { Blood collection equipment } \\
\text { Safety cabinet } \\
\text { Packaging and transportation materials }\end{array}$ \\
\hline Closing ceremony & $\begin{array}{l}\text { Speeches by WHO country office and DOH; } \\
\text { presentation of certificates }\end{array}$ & Certificates of participation \\
\hline
\end{tabular}

* Modules and guide are available at http://www.wpro.who.int/philippines/mediacentre/features/ebolatraining_materials/en/.

DOH, Department of Health; EVD, Ebola virus disease; PPE, personal protective equipment; UV, ultraviolet rays; WHO, World Health Organization. 
Figure 1. Donning and doffing PPE during the Philippine DOH Ebola preparedness workshop*

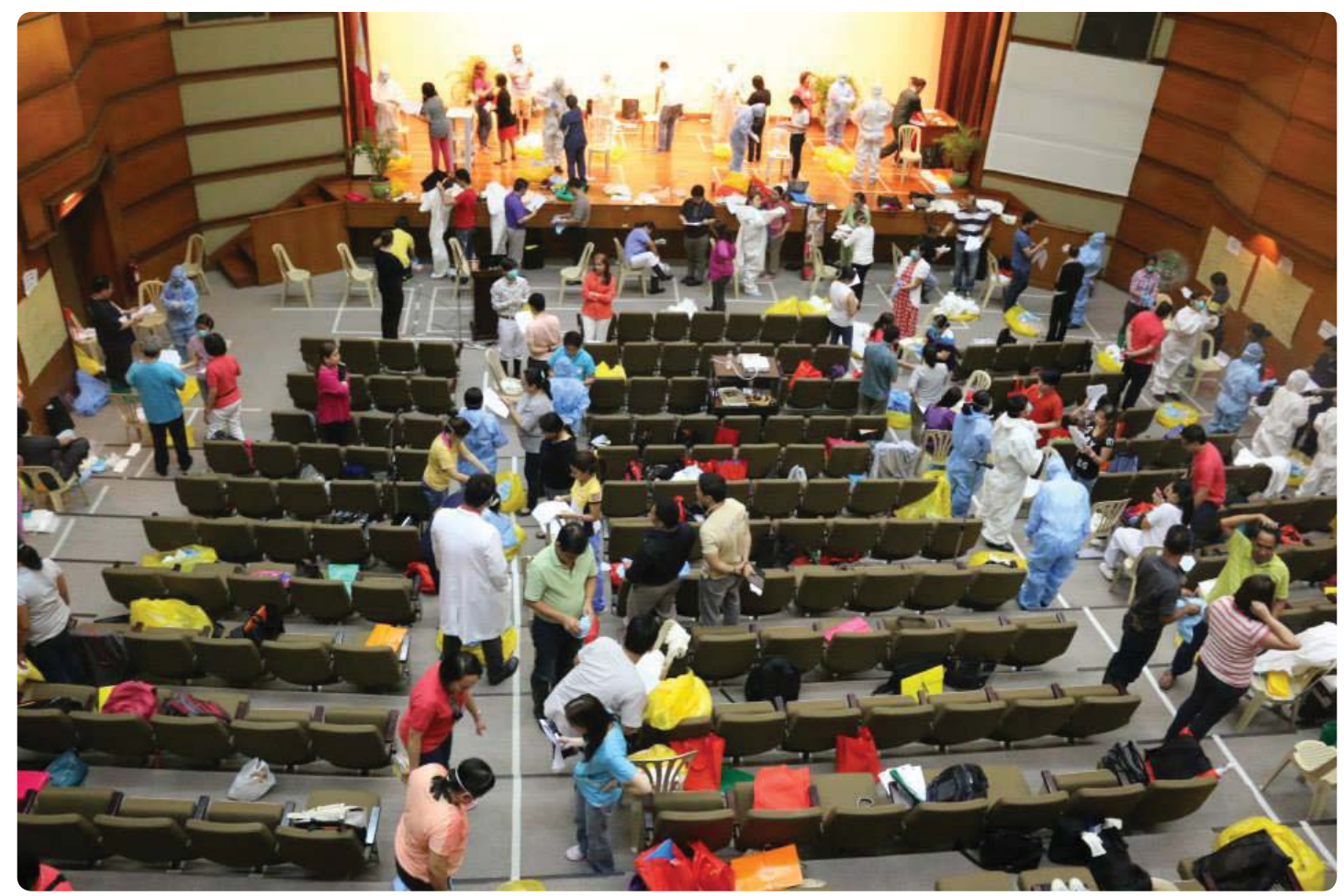

Source: Photo taken by the Research Institute for Tropical Disease photographer.

* Each health-care provider worked with a trained observer. Facilitators supervised groups of participants. Tape on the floor helped simulate workflow by identifying low and high risk areas.

medical technologists' sessions included opportunities to practise venepuncture and use laboratory equipment while wearing EVD PPE. At the closing session on Day 3, the Director of RITM and the WHO Representative or their delegates gave closing speeches and presented certificates of participation.

\section{Participants}

Since the $\mathrm{DOH}$ wished to rapidly and extensively distribute EVD knowledge and skills, three initial workshops were held from 28 October to 13 November 2014 with large numbers of participants in each. Hospitals selected by the $\mathrm{DOH}$ from each province were asked to send a team of five including at least one doctor, one nurse and one medical technologist. Batches 1, 2 and 3 had 127, 115 and 122 participants, respectively, from 78 hospitals (21 regional hospitals, 22 private hospitals and 35 local government hospitals).

The training programme for each batch of trainees was modified as new evidence was reported in the
Figure 2. Water-based red paint has been applied to a participant's PPE to simulate extensive contamination by blood*

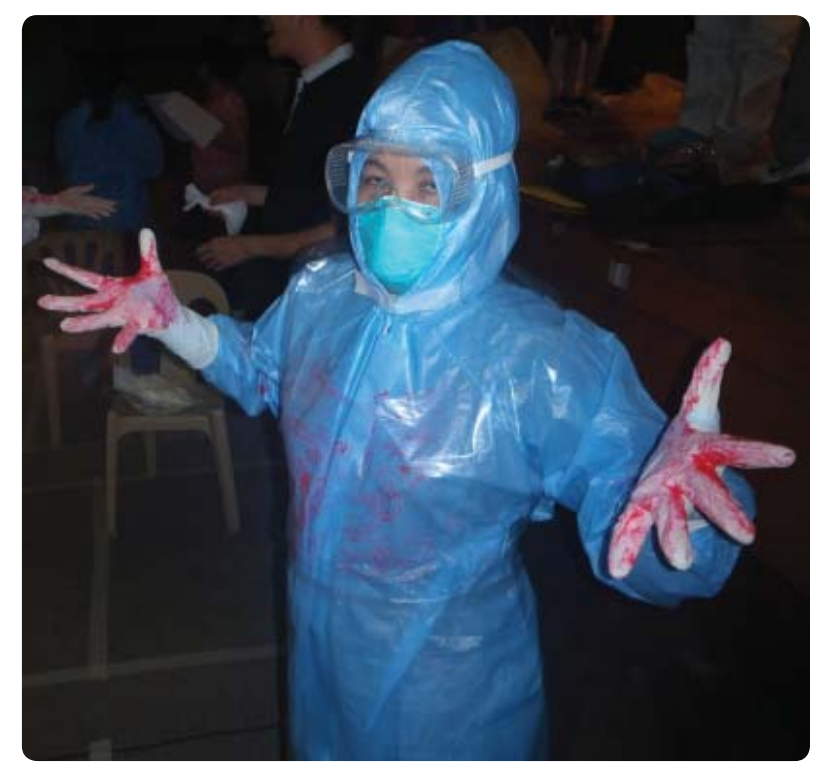

Source: Photo taken by Rick Speare.

* Gloves, gown and the clear, disposable apron are contaminated. 
literature or online by the Centers for Disease Control and Prevention (CDC) and WHO. ${ }^{16,17}$

\section{Evaluation}

Three tools were used to evaluate the workshop: a preand post-workshop test, two evaluation forms postworkshop and One Minute Reflections $(\mathrm{OMR})^{18}$ on Days 1 and 2. The test was developed by WHO consultants and piloted on RITM medical and nursing staff; the RITM evaluation form is used routinely for all workshops, and the EVD-specific evaluation form was a modification of the Johns Hopkins Hospital form used for EVD training workshops. All questionnaires were anonymous.

Effect of the workshop on knowledge was tested using a pre- and post-workshop test administered on Day 1 before the lectures commenced and on Day 3 before the final practical session on PPE. Knowledge was assessed by 10 questions. Confidence in being able to manage EVD was assessed on a five-point Likert scale (strongly disagree, disagree, neither disagree or agree, agree and strongly agree) in response to the statement: "I am confident that I can be safe when caring for a patient with Ebola virus disease." The answers were summarized and presented to the participants before the closing session on Day 3.

At the end of activities on Days 1 and 2 participants were asked to complete the OMR which asked two questions: (1) What was the most useful, meaningful or intriguing thing/s that you learnt during this day? and (2) what question/s remains uppermost in your mind as we end this day? The responses from the OMR were addressed in the first sessions on Days 2 and 3.

\section{Statistical analysis}

Pre- and post-workshop test: If a response to one of the 10 knowledge questions was missing, it was set to being incorrect. The number of missing values per question ranged between 0 and 4 for the pre-workshop test and between 0 and 6 for the post-workshop test. The 10 knowledge questions were recoded to 0 for "incorrect" and 1 for "correct" and added up to get the overall number of correct answers. This outcome variable was logarithmically transformed to achieve approximate normal distribution for the linear regression analysis. Pre- and post-workshop participants were analysed as unpaired data because questionnaires could not be linked.

Categorical characteristics are described using absolute and relative frequencies. Age was described using mean value and standard deviation. The number of correct answers given to the 10 knowledge questions was described using median value and inter-quartile range (IQR). Confidence intervals of $95 \%$ were calculated for correct answers to knowledge questions; pre- and postworkshop test results were compared using chi-square tests. The overall logarithmically transformed number of correct answers pre- and post-training were compared using linear regression. Linear regression analysis was conducted to analyse whether profession, age and gender showed independent effects on the logarithmically transformed number of correct answers post-workshop. Profession and gender were dummy coded for this analysis, while age was initially considered, continuous and was then categorized using the quartiles and dummy coded. Chi-square tests were used to assess effects of age, gender and profession on level of confidence dealing with an Ebola case post-workshop. All analysis was adjusted for the cluster effect of the three workshops. Analysis was conducted using STATA, release 12.1 (StataCorp LP, College Station, Texas). Since this was an operational evaluation and findings were progressively used to improve the workshop, ethics approval was not sought.

\section{RESULTS}

\section{Participants}

A total of 285 participants ( $78.3 \%$ of all participants) and 364 participants (100\% of all participants) completed the pre- and post-workshop tests, respectively. For the pre- and post-workshop tests, respectively, participants were doctors (33.3\% and $35.0 \%$ ), nurses $(42.9 \%$ and $40.0 \%$ ), medical technologists ( $20.3 \%$ and $20.1 \%$ ) and others (3.4\% and $4.5 \%$ ). Participants who completed the pre- and post-training participants were predominantly female (59.6\% and $61.9 \%$, respectively) and mean ages and ranges were the same at 38.2 (21 to 62 years).

\section{Improvement in knowledge}

Of the 10 knowledge questions, three were correctly answered by more than $90 \%$ of pre-workshop test 
Table 2. Percentage and $95 \%$ confidence interval of correct responses to 10 knowledge questions pre- and post-workshop*

\begin{tabular}{|c|c|c|c|c|}
\hline Knowledge questions & $\begin{array}{l}\text { Pre-workshop } \\
\quad(n=285) \\
\%[95 \% \mathrm{Cl}]^{\dagger}\end{array}$ & $\begin{array}{l}\text { Post-workshop } \\
(n=364) \\
\%[95 \% \mathrm{Cl}]^{\dagger}\end{array}$ & $\%$ change & $p$-value \\
\hline $\begin{array}{l}\text { 1. The maximum incubation period of Ebola virus disease } \\
\text { (EVD) is } 42 \text { days (False) }\end{array}$ & $80.0 \% ;[62.4,97.6]^{*}$ & $90.1 \% ;[77.8,100]$ & 10.1 & 0.254 \\
\hline $\begin{array}{l}\text { 2. A person infected with Ebola virus can pass on the } \\
\text { virus before symptoms begin (False) }\end{array}$ & $55.8 \% ;[26.1,85.5]$ & $89.0 \% ;[73.8,100]$ & 33.2 & 0.018 \\
\hline $\begin{array}{l}\text { 3. Multiple choice question on transmission routes for } \\
\text { EVD }\end{array}$ & $34.0 \% ;[11.3,56.7]$ & $59.1 \% ;[44.6,73.5]$ & 25.1 & 0.055 \\
\hline $\begin{array}{l}\text { 4. Soap and water is an effective method of hand hygiene } \\
\text { when caring for patients with EVD (True) }\end{array}$ & $80.4 \% ;[70.8,89.9]$ & $63.5 \% ;[33.6,93.3]$ & -16.9 & 0.081 \\
\hline $\begin{array}{l}\text { 5. While working in personal protective equipment, } \\
\text { health-care workers caring for patients with EVD } \\
\text { should have no skin exposed (True) }\end{array}$ & $96.8 \% ;[94.0,99.7]$ & $98.9 \% ;[96.7,100]$ & 2.1 & 0.073 \\
\hline $\begin{array}{l}\text { 6. The World Health Organization recommends double } \\
\text { gloves when caring for a suspect or confirmed Ebola } \\
\text { patient (True) }\end{array}$ & $85.3 \% ;[71.7,98.8]$ & $98.4 \% ;[96.2,100]$ & 13.1 & 0.007 \\
\hline $\begin{array}{l}\text { 7. Multiple choice question on the correct proportions to } \\
\text { make up } 0.5 \% \text { bleach disinfectant }\end{array}$ & $19.6 \% ;[12.8,26.5]$ & $86.5 \% ;[65.0,100]$ & 66.9 & 0.009 \\
\hline $\begin{array}{l}\text { 8. Waste from an Ebola patient in a typical Philippine } \\
\text { hospital can be discarded as is usual (False) }\end{array}$ & $95.1 \% ;[91.1,99.1]$ & $96.7 \% ;[96.3,97.1]$ & 1.6 & 0.161 \\
\hline $\begin{array}{l}\text { 9. When caring for a suspected or confirmed Ebola } \\
\text { patient, do not perform any blood tests except an } \\
\text { Ebola test (False) }\end{array}$ & $76.1 \% ;[60.7,91.6]$ & $75.0 \% ;[47.2,100]$ & -1.1 & 0.719 \\
\hline 10. A person dead from EBV can be embalmed (False) & $90.5 \% ;[80.8,100]$ & 97.3\%; [91.8, 100] & 6.8 & 0.188 \\
\hline
\end{tabular}

participant (no skin exposed in EVD PPE, EVD waste handled differently, no embalming with EVD) (Table 2). For the other seven questions, pre-workshop knowledge was poor $(<50 \%$ correct) for two questions (transmission routes of EVD, correct mixing of $0.5 \%$ bleach). The percentage of correct answers rose by $10 \%$ or more in the post-workshop test for five questions (three of them statistically significant), remained largely unchanged for four (three of which had more than 90\% correct in pretest) and one fell by 16.9\% (soap and water in EVD) but this did not achieve statistical significance (Table 2).

The percentage of participants who correctly answered all 10 questions was $2.8 \%$ (8 of 285) and $22.5 \%$ (82 to 364 ) pre- and post-workshop, respectively. The number of questions correctly answered by participants rose from a pre-workshop median of seven (IQR $=6$ to 8 ; range 3 to 10 ) to a post-workshop median of nine $(I Q R=8$ to 9 ; range 4 to 10$)(P<0.009)$ (Figure 3).
Figure 3. Percentage of knowledge questions correctly answered pre- and post-workshop

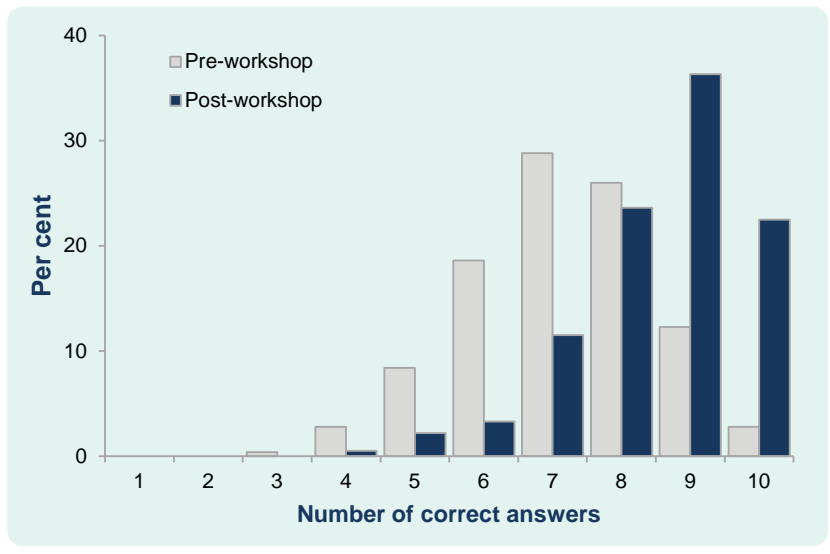

Profession (nurse $P=0.775$, medical technologist $P=0.431$, other $P=0.335$, doctor $=$ reference group), age (30-39 years $P=0.271 ; 40-44$ years $P=0.273$; $\geq 45$ years $P=0.728$; reference $<30$ years) and gender $(P=0.071)$ showed no significant independent 
Table 3. Associations between number of correct responses and level of confidence post-workshop and age, gender and profession

\begin{tabular}{|c|c|c|c|c|}
\hline Influencing characteristics & $\begin{array}{l}\text { Median number of } \\
\text { correct responses } \\
\text { post-workshop [IQR] }\end{array}$ & $p$-value* & $\begin{array}{l}\% \text { agreeing or strongly agreeing with } \\
\text { "I am confident that I can be safe when } \\
\text { caring for a patient with Ebola virus } \\
\text { disease" post-workshop }\end{array}$ & $p$-value ${ }^{\dagger}$ \\
\hline \multicolumn{5}{|l|}{ Profession } \\
\hline Doctor & $9[8,9]$ & Reference & 91.7 & \multirow{4}{*}{0.458} \\
\hline Nurse & $9[8,10]$ & 0.775 & 86.6 & \\
\hline Laboratory worker & $8[8,9]$ & 0.431 & 84.7 & \\
\hline Other & $9[6.75,9]$ & 0.335 & 78.6 & \\
\hline \multicolumn{5}{|l|}{ Gender } \\
\hline Female & $9[8,10]$ & Reference & 86.7 & \multirow{2}{*}{0.404} \\
\hline Male & $9[8,9]$ & 0.071 & 91.3 & \\
\hline \multicolumn{5}{|l|}{ Age } \\
\hline $0-29$ years & $9[8,9]$ & Reference & 91.5 & \multirow{4}{*}{0.412} \\
\hline 30-39 years & $9[8,10]$ & 0.271 & 91.2 & \\
\hline 40-44 years & $9[8,9]$ & 0.273 & 88.2 & \\
\hline 45 years and above & $9[8,10]$ & 0.728 & 80.8 & \\
\hline
\end{tabular}

* $p$-values are results of a linear regression model for post-workshop outcome including profession, age and gender as independent variables. $p$-values are results of chi-square tests. $P$-values are adjusted for cluster-effect.

$I Q R$, inter-quartile range.

Table 4. Evaluation of the EVD workshop using the general RITM form $(n=328)$

\begin{tabular}{lccccc}
\hline Section & Poor & Acceptable & Satisfactory & Very good & Excellent \\
\hline Content of lectures & $0.0 \%$ & $0.0 \%$ & $2.1 \%$ & $34.8 \%$ & $63.1 \%$ \\
Lecturers/presentations & $0.0 \%$ & $0.3 \%$ & $4.6 \%$ & $42.7 \%$ & $52.4 \%$ \\
Overall rating & $0.0 \%$ & $0.4 \%$ & $4.7 \%$ & $53.3 \%$ & $41.6 \%$ \\
\hline
\end{tabular}

effects on the number of correct answers post-workshop Evaluations

(Table 3).

\section{Improvement in confidence}

Participants' level of confidence in safely caring for an EVD patient rose markedly by the end of the workshop $(P=0.018)$. Pre-workshop, $27.3 \%$ disagreed or strongly disagreed with the statement: "I am confident that I can be safe when caring for a patient with Ebola virus disease," while post-training this percentage fell to $2.6 \%(P=0.018)$. On the other hand, pre-workshop, $32.5 \%$ of participants agreed or strongly agreed with the statement; post-training this percentage had risen to $87.2 \%$. The post-workshop level of confidence was not influenced by age $(P=0.412)$, gender $(P=0.404)$ or profession $(P=0.458)$ (Table 3 ).
Ratings in both evaluation forms were at the high end of a five-point Likert scale (Tables 4 and 5 ). The overall rating for the workshop was excellent $(72.2 \%)$, good (26.7\%), fair $(0.6 \%)$ and poor (0\%) (Table 4$)$. To the question "Do you feel you are more prepared to screen for and manage patients with Ebola?" 96.4\% of participants answered "Yes" (Table 5).

The OMR provided a useful means of addressing questions that were left unanswered after Days 1 and 2 . These questions fell mainly into two areas: knowledge and support. The former category consisted largely of questions about the disease. The latter category included detailed questions about how things would be done if an EVD case occurred; where the specialized items of PPE 
Table 5. Ratings on EVD-specific evaluation form $(n=333)$

\begin{tabular}{|c|c|c|c|c|c|}
\hline Section & $\begin{array}{l}\text { Strongly } \\
\text { disagree }\end{array}$ & Disagree & $\begin{array}{l}\text { Neither agree } \\
\text { or disagree }\end{array}$ & Agree & $\begin{array}{l}\text { Strongly } \\
\text { agree }\end{array}$ \\
\hline \multicolumn{6}{|l|}{ Course objectives and content } \\
\hline $\begin{array}{l}\text { I understood what the training was designed to } \\
\text { achieve. }\end{array}$ & $0.0 \%$ & $0.0 \%$ & $1.8 \%$ & $37.8 \%$ & $60.1 \%$ \\
\hline I feel like the training objectives were achieved. & $0.0 \%$ & $0.3 \%$ & $3.3 \%$ & $43.1 \%$ & $53.3 \%$ \\
\hline I know how to prepare for Ebola at my facility. & $0.0 \%$ & $0.6 \%$ & $9.8 \%$ & $53.4 \%$ & $36.2 \%$ \\
\hline $\begin{array}{l}\text { I understand infection control in management of } \\
\text { Ebola patients. }\end{array}$ & $0.0 \%$ & $0.3 \%$ & $3.8 \%$ & $49.1 \%$ & $46.7 \%$ \\
\hline $\begin{array}{l}\text { I feel confident applying infection control in } \\
\text { managing Ebola patients. }\end{array}$ & $0.0 \%$ & $1.2 \%$ & $11.5 \%$ & $58.0 \%$ & $29.0 \%$ \\
\hline $\begin{array}{l}\text { I know how to screen and triage potential Ebola } \\
\text { patients. }\end{array}$ & $0.0 \%$ & $0.3 \%$ & $3.9 \%$ & $48.5 \%$ & $47.3 \%$ \\
\hline \multicolumn{6}{|l|}{ Training materials } \\
\hline $\begin{array}{l}\text { I found the training materials for this workshop } \\
\text { to be well organized. }\end{array}$ & $0.0 \%$ & $1.8 \%$ & $2.4 \%$ & $46.7 \%$ & $49.1 \%$ \\
\hline $\begin{array}{l}\text { I think the training materials will be useful in the } \\
\text { future. }\end{array}$ & $0.0 \%$ & $1.5 \%$ & $8.0 \%$ & $46.3 \%$ & $43.7 \%$ \\
\hline \multicolumn{6}{|l|}{ Trainers' skills } \\
\hline $\begin{array}{l}\text { The trainers stated all session objectives clearly } \\
\text { and they were easy to follow. }\end{array}$ & $0.0 \%$ & $0.6 \%$ & $2.9 \%$ & $48.4 \%$ & $47.8 \%$ \\
\hline $\begin{array}{l}\text { The trainers were able to assist participants } \\
\text { when questions or difficulties arose. }\end{array}$ & $0.0 \%$ & $0.0 \%$ & $4.4 \%$ & $47.2 \%$ & $48.4 \%$ \\
\hline $\begin{array}{l}\text { The trainers were knowledgeable about the } \\
\text { topic. }\end{array}$ & $0.0 \%$ & $0.6 \%$ & $1.8 \%$ & $39.9 \%$ & $57.7 \%$ \\
\hline \multicolumn{6}{|l|}{ Course administration } \\
\hline The training schedule was acceptable. & $0.0 \%$ & $0.9 \%$ & $6.5 \%$ & $48.7 \%$ & $43.9 \%$ \\
\hline The training was well organized. & $0.0 \%$ & $0.9 \%$ & $6.5 \%$ & $50.4 \%$ & $42.1 \%$ \\
\hline
\end{tabular}

could be obtained; funding for preparedness; and the roles of institutions, DOH and other government bodies. Questions on knowledge were answered by lecturers and RITM staff. On the last day, the Director of the Emerging Infectious Disease Control Programme was on hand to answer operational questions. His attendance was very important because the policy situation is dynamic and evolving.

\section{DISCUSSION}

This three day workshop on hospital preparedness for EVD raised knowledge and increased the confidence of participants. Two areas of knowledge that were not as well understood that soap and water is effective for hand hygiene in EVD and the transmission of Ebola virus. The change in the former is understandable since during the practical sessions alcohol-based hand rubs were used for hand hygiene practice and to decontaminate gloves between doffing steps. Soap and water is recommended by WHO for hand hygiene for EVD if alcohol-based hand rubs are unavailable and as the preferred method if hands are visibly soiled. ${ }^{19}$ However, in many resourcelimited settings sinks may not be available at point of care or may not have adequate soap or hand drying materials. ${ }^{20}$ This has been identified as a current problem in Liberian hospitals. ${ }^{21,22}$ In the workshop, emphasizing the indications for soap and water may have increased the correct answers.

Epidemiological studies in African communities have shown that direct contact with a symptomatic case of EVD is required for transmission. ${ }^{23-25}$ Interestingly, although an early study showed no transmission in the community without direct contact, one of the primary cases acquired EVD while visiting the local hospital in Sudan with no identified contact with a hospitalized EVD case. ${ }^{23}$ Conveying how EVD transmits in the health care setting remains a difficult issue. ${ }^{26,27}$ When two nurses in the USA acquired EVD while wearing PPE with no apparent breaches in protocol, ${ }^{28}$ standards of PPE for EVD were upgraded by both $C D C$ and 
WHO. ${ }^{16,17}$ In hospitals and EVD isolation units the concept of "direct transmission" is confusing when it also includes transmission by needlestick, droplets and splashes and when aerosol transmission associated with clinical procedures (i.e. intubation) must be regarded as a risk. ${ }^{26}$ Although the correct answers for the question on transmission increased, it remained unacceptably low at $59.1 \%$. We need to develop a new approach for conveying the complexities of transmission routes in the health-care setting.

The increase in level of confidence was verified by the pre- and post-workshop test and by two questions in the EVD-specific evaluation form. Improvement in the knowledge of participants, particularly in the practice of proper donning and doffing of PPE, could have contributed to this. In the OMR, participants often mentioned PPE as the most useful thing learnt. This workshop appeared to be effective in providing baseline training to raise awareness in large numbers of HCWs.

Screening and triage procedures were emphasized in lectures and reinforced by a practical session using the DOH screening and triage forms on six cases, illustrating the importance of a detailed travel, contact and illness history in the non-Ebola setting. Failure to screen and triage patients in the hospital setting in Liberia has led to infection of HCWs. ${ }^{21,29}$ Screening and triage are essential strategies to rapidly detect EVD patients in countries not affected by EVD and to prevent transmission.

We could find no specific guidelines for training $\mathrm{HCWs}$ in non-Ebola countries to be prepared to manage EVD. The approach we used trained teams of key health professionals from hospitals across the Philippines in the basics with the aim that they would train others when they returned home. In developed countries the focus appears to be on major hospitals, some designated for high consequence pathogens such as Ebola, to do intensive preparatory training. ${ }^{30-32}$ The former approach may be more suitable in countries with limited resources. In these settings, non-specialized clinicians will be expected to participate in the management of EVD patients. Providing basic training for large groups of HCWs may best protect the majority of HCWs. Once a case of EVD is identified, more intensive training can be provided to those HCWs managing the case to quickly build on the basic knowledge and skills. Although knowledge may not always be retained over time, brief educational intervention of eight hours duration for disaster preparedness was proven to be effective and to have a long-term impact on nurses' knowledge. ${ }^{33}$

Limitations include use of the same test pre- and post-workshop, meaning increases in knowledge may be test- rather than disease-specific; and the $27.7 \%$ increase in responses for the post-workshop test which may breach the assumption that the pre- and postworkshop populations were the same. However, the professional, age and gender compositions of the samples were similar.

Although the context of the training was specific to the Philippines, the workshop could be adapted to other countries by substituting the Philippine $\mathrm{DOH}$ Interim Guidelines for EVD with each country's own guidelines and omitting the lecture on Ebola Reston since this species of Ebola virus is endemic only in the Philippines and China. ${ }^{34,35}$ Mention of Ebola Reston in the background lecture on Ebola would be adequate for other developing countries.

\section{CONCLUSIONS}

The three-day workshop developed by the Philippine DOH to prepare hospital staff for EVD was effective at increasing the level of knowledge about EVD and the level of confidence in managing EVD safely. In an Ebola outbreak, additional specialized training in use of PPE would be needed for those caring for EVD patients in hospital to reinforce the baseline training. This workshop could be adapted for use in other developing countries preparing their hospital staff to rapidly detect, isolate and safely manage EVD cases.

\section{Conflicts of interest}

None declared.

\section{Funding}

Development and evaluation of the workshop and employment of WHO consultants (Speare, Rhymer, Curless, Lynch, Gavin and Black) was funded by the Department for International Development. Philippine 
DOH provided funds to conduct the workshop. All staff of RITM, DOH and WHO were funded by their respective employers under routine funding.

\section{Acknowledgement}

We thank a large number of staff of RITM for logistic support in developing and conducting workshops and the IT staff of RITM in particular for assistance in entering data from evaluation forms.

\section{References:}

1. Statement on the first meeting of the IHR Emergency Committee on the 2014 Ebola outbreak in West Africa. Geneva, World Health Organization, 8 August 2014 (http://www.who.int/media centre/news/statements/2014/ebola-20140808/en/, accessed 25 November 2014).

2. Ebola Response Roadmap Situation Report 24 December 2014. Geneva, World Health Organization, 2014 (http://apps.who.int/ iris/bitstream/10665/146311/1/roadmapsitrep_24Dec14_eng. pdf?ua=1, accessed 30 December 2014).

3. International Health Regulations (2005) Second edition. Geneva, World Health Organization, 2008 (http://whqlibdoc. who.int/publications/2008/9789241580410_eng.pdf, accessed 24 November 2014).

4. Resolution adopted by the General Assembly on 19 September: 69/1. Measures to contain and combat the recent Ebola outbreak in West Africa. New York, United Nations General Assembly, 2014 (http://www.un.org/en/ga/search/view_doc.asp?symbol=A/ RES/69/1, accessed 25 November 2014).

5. Statistical Tables on Overseas Filipino Workers (OFW): 2013. Manila, National Statistics Office, 2014 (http://census.gov.ph/ content/statistical-tables-overseas-filipino-workers-ofw-2013, accessed 25 November 2014).

6. Stock estimate of Filipinos overseas as of December 2012. Manila, Commission on Filipinos Overseas, 2013 (http://cfo. gov.ph/images/stories/pdf/StockEstimate2012.pdf, accessed 26 November 2014).

7. Anonymous. Overseas Filipino Workers. Manila, Wikipilipinas, 2008 (http://en.wikipilipinas.org/index.php/Overseas_Filipino_ Workers, accessed 21 December 2014).

8. Pamaran RR et al. Epidemiological characterization of influenza A(H1N1)pdm09 cases from 2009 to 2010 in Baguio City, the Philippines. PLoS One, 2013, 11;8(11):e79916. doi:10.1371/ journal.pone.0079916 pmid:24244578

9. Anonymous. SARS outbreak in the Philippines. Weekly Epidemiological Record, 2003, 78:189-192. pmid:12836452

10. Corpuz A, Banatin CA. Surveillance in Post Extreme Emergencies and Disasters (SPEED). Early Warning Alert and Response Network Humanitarian Emergency Conference, Geneva, 17-19 March 2014.

11. Ebola and Marburg virus disease epidemics: preparedness, alert, control, and evaluation - Interim version 1.1. Geneva, World Health Organization, 2014 (http://www.who.int/csr/ disease/ebola/PACE_outbreaks_ebola_marburg_en.pdf, accessed 26 November 2014).

12. Med Box. Ebola toolbox. Wursburg, Department of Humanitarian Collaboration Medical Missions Institute, Advisory Organization for International Health (http://www.medbox.org/ebola-trainingmaterial/listing, accessed 20 November 2014).

13. Ebola ebriefing. Barcelona, Médecins Sans Frontières, 2014 (http://ecampus.msf.org/moodlemsf/mod/page/view.php?id = 22246, accessed 26 November 2014).

14. 2014 West Africa Ebola virus disease outbreak briefing pack: Foreign Medical Teams International Response. Geneva, World Health Organization, 2014: p. 24. (http://ecampus. msf.org/moodlemsf/pluginfile.php/30615/block_html/content/ WHO\%20Briefing\%20Foreign\%20Medical\%20Teams.pdf, accessed 26 November 2014).

15. Training on hospital management of Ebola Virus Disease (EVD). Manila, World Health Organization Regional Office for the Western Pacific, 2014 (http://www.wpro.who.int/philippines/ mediacentre/features/ebolatraining_materials/en/, accessed 5 January 2015).

16. Guidance on personal protective equipment to be used by healthcare workers during management of patients with Ebola virus disease in U.S. hospitals, including procedures for putting on (donning) and removing (doffing). Atlanta, Centers for Disease Control and Prevention, 2014 (http://www.cdc.gov/vhf/ebola/hcp/ procedures-for-ppe.html, accessed 27 November 2014).

17. WHO updates personal protective equipment guidelines for Ebola response. Geneva, World Health Organization, 2014 (http://www.who.int/mediacentre/news/releases/2014/ebola-ppeguidelines/en/, accessed 27 November 2014).

18. Redman-Maclaren ML et al. Research workshop to research work: initial steps in establishing health research systems on Malaita, Solomon Islands. Health Research Policy and Systems/ BioMed Central, 2010, 8:33. doi:10.1186/1478-4505-8-33 pmid:21034512

19. Guideline on hand hygiene in health care in the context of filovirus disease outbreak response. Geneva, World Health Organization, 2014 (http://apps.who.int/iris/bitstream/10665/ 144578/1/WHO_HIS_SDS_2014.15_eng.pdf?ua=1, accessed 5 December 2014).

20. Devnani $M$ et al. A survey of hand-washing facilities in the outpatient department of a tertiary care teaching hospital in India. Journal of Infection in Developing Countries, 2011, 5:114-118. doi:10.3855/jidc.1003 pmid:21389590

21. Matanock $A$ et al. Ebola virus disease cases among health care workers not working in ebola treatment units - Liberia, JuneAugust, 2014. Morbidity and Mortality Weekly Report, 2014, 63:1077-1081. pmid:25412067

22. Kilmarx PH et al. Ebola virus disease in health care workers Sierra Leone, 2014. Morbidity and Mortality Weekly Report, 2014, 63:1168-1171. pmid:25503921

23. Baron RC, McCormick JB, Zubeir OA. Ebola virus disease in southern Sudan: hospital dissemination and intrafamilial spread. Bulletin of the World Health Organization, 1983, 61:997-1003. pmid:6370486

24. Dowell SF et al. Transmission of Ebola hemorrhagic fever: a study of risk factors in family members, Kikwit, Democratic Republic of the Congo, 1995. Commission de Lutte contre les Epidémies à Kikwit. The Journal of Infectious Diseases, 1999, 179 Suppl 1;S87-91. doi:10.1086/514284 pmid:9988169

25. Review of human-to-human transmission of Ebola virus. Atlanta, Centers for Disease Control and Prevention, 2014 (http://www.cdc. gov/vhf/ebola/transmission/human-transmission.html, accessed 2 November 2014).

26. Jones RM, Brosseau LM. Ebola virus transmission via contact and aerosol - a new paradigm. Center for Infectious Disease Research and Policy, 2014 (http://www.cidrap. umn.edu/news-perspective/2014/11/commentary-ebola- 
virus-transmission-contact-and-aerosol-new-paradigm, accessed 20 November 2014).

27. Brisseau LM, Jones RM. Health workers need optimal respiratory protection for Ebola. Center for Infectious Disease Research and Policy, 2014 (http://www.cidrap.umn.edu/newsperspective/2014/09/commentary-health-workers-need-optimalrespiratory-protection-ebola, accessed 5 November 2014).

28. Chevalier MS et al. Ebola virus disease cluster in the United States - Dallas county, Texas, 2014. Morbidity and Mortality Weekly Report, 2014, 63:1087-1088. pmid:25412069

29. Forrester JD et al.; Centers for Disease Control and Prevention (CDC). Cluster of Ebola cases among Liberian and U.S. health care workers in an Ebola treatment unit and adjacent hospital Liberia, 2014. Morbidity and Mortality Weekly Report, 2014, 63:925-929. pmid:25321070

30. Bannister B, Prygodzicz A, Ippolito G; ETIDE Working Group. Training health care workers to face highly infectious diseases. Clinical Microbiology and Infection, 2009, 15:740-742. doi:10.1111/j.1469-0691.2009.02872.x pmid: 19486076
31. Anonymous. Hospitals prepare plans, drill staff to ensure that potential Ebola patients are identified, isolated, and managed safely. ED Magazine, 2014, 26:138-141.

32. Ashino $Y$ et al. Ebola Virus Disease: Preparedness in Japan. Disaster Medicine and Public Health Preparedness, 2014 1-5. Epub ahead of print. doi:10.1017/dmp.2014.130 pmid:25399765

33. Pesiridis $T$ et al. Development, implementation and evaluation of a disaster training programme for nurses: A Switching Replications randomized controlled trial. Nurse Education in Practice, 2014, pii: S1471-5953(14)00016-X. Epub ahead of print. doi:10.1016/j.nepr.2014.02.001 pmid:24560740

34. Miranda ME, Miranda NLJ. Reston ebolavirus in humans and animals in the Philippines: a review. The Journal of Infectious Diseases, 2011, 204 Suppl 3;5757-760. doi:10.1093/infdis/ jir296 pmid:21987747

35. Pan $Y$ et al. Reston virus in domestic pigs in China. Archives of Virology, 2014, 159:1129-1132. doi:10.1007/s00705-0121477-6 pmid:22996641 